University of Nebraska - Lincoln

DigitalCommons@University of Nebraska - Lincoln

Faculty Publications: Department of Entomology

Entomology, Department of

2001

Influence of Western Corn Rootworm (Coleoptera:

Chrysomelidae) Larval Injury on Yield of Different Types of Maize

Mario A. Urías-López

INIFAP, Santiago Ixcuintla Nay, Mexico

Lance J. Meinke

University of Nebraska-Lincoln, Imeinke1@unl.edu

Follow this and additional works at: https://digitalcommons.unl.edu/entomologyfacpub

Part of the Entomology Commons

Urías-López, Mario A. and Meinke, Lance J., "Influence of Western Corn Rootworm (Coleoptera: Chrysomelidae) Larval Injury on Yield of Different Types of Maize" (2001). Faculty Publications: Department of Entomology. 265.

https://digitalcommons.unl.edu/entomologyfacpub/265

This Article is brought to you for free and open access by the Entomology, Department of at DigitalCommons@University of Nebraska - Lincoln. It has been accepted for inclusion in Faculty Publications: Department of Entomology by an authorized administrator of DigitalCommons@University of Nebraska - Lincoln. 


\title{
Influence of Western Corn Rootworm (Coleoptera: Chrysomelidae) Larval Injury on Yield of Different Types of Maize
}

\author{
MARIO A. URÍAS-LÓPEZ1 ${ }^{1}$ AND LANCE J. MEINKE ${ }^{2}$
}

Department of Entomology, University of Nebraska, Lincoln, NE 68583-0816

\begin{abstract}
J. Econ. Entomol. 94(1): 106-111 (2001)
ABSTRACT Two field experiments were conducted in 1995-1996 to determine if there are common yield responses among maize hybrids to larval western corn rootworm, Diabrotica virgifera virgifera LeConte injury. Three yellow dent hybrids, five white food grade dent hybrids, and a popcorn hybrid were included in the study. The minimum level of rootworm injury as measured by root damage ratings (3.2-4.2) that significantly reduced yield was similar across the hybrids included in the study. However, the pattern of yield response to different rootworm injury levels varied among hybrids. This suggests that maize hybrids may inherently differ in their ability to tolerate rootworm injury and partition biomass in response to injury and other stresses. The complex interaction among hybrid, level of injury, and other stresses suggests that a common western corn rootworm injuryyield relationship may not exist within maize.
\end{abstract}

KEY WORDS Diabrotica virgifera virgifera, corn, yield

THE WESTERN CORN rootworm, Diabrotica virgifera virgifera LeConte, is an economically important insect pest of maize in the United States (Levine and Oloumi-Sadeghi 1991). Costs associated with managing corn rootworms in continuous maize are annually one of the largest expenditures for insect management in the Corn Belt (Metcalf 1986, Steffey et al. 1994). Larvae feed on root hairs and cortical tissue (Chiang 1973, Riedell and Kim 1990) and tunnel inside roots (Branson 1986, Riedell 1990), which can lead to root pruning (Palmer and Kommedahl 1969) and grain yield reduction (Turpin et al. 1972, Apple et al. 1977, Spike and Tollefson 1991, Godfrey et al. 1993a, Gray and Steffey 1998). Yield responses of maize to infestations of western corn rootworm larvae have been shown to vary under different environmental conditions and with severity of damage (Chiang et al. 1980, Spike and Tollefson 1991, Riedell et al. 1992, Gray and Steffey 1998). Low to moderate levels of injury may result in no yield loss or actually increase yield (Riedell et al. 1992), whereas severe damage has been shown to cause yield reductions of $40-50 \%$ (Chiang et al. 1980, Godfrey et al. 1993a).

A relationship between root injury and yield loss was established by Turpin et al. (1972) and has been modified in subsequent studies (Stamm et al. 1985, Mayo 1986, Sutter et al. 1990, Davis 1994, Gray and Steffey 1998). Root damage scales based on levels of larval injury (i.e., Mayo 1986) at the end of the larval period have been used as economic injury indices. A root rating of 3.0 (Mayo 1986) on a 1-6 scale (Hills and

\footnotetext{
${ }^{1}$ INIFAP, Apartado Postal 100, 63300 Santiago Ixcuintla Nay, Mex-

${ }^{2}$ To whom reprint requests should be addressed.
}

Peters 1971) has been commonly used by researchers and industry as an index of the level of root injury that potentially could lead to economic yield loss. However, results of some studies indicate that economic loss may not occur under certain conditions until root injury ratings are much greater than 3.0 (Sutter et al. 1990, Gray et al. 1993, Davis 1994). Gray and Steffey (1998) in a recent study found that hybrid characteristics and environmental conditions greatly influence the level of root injury needed to cause economic loss. They provided examples of the dynamic nature of yield response to rootworm injury and reported that root injury ratings lower than 3.0 under certain conditions can result in economic yield loss.

The search for sources of resistance to corn rootworm that can be used in traditional breeding programs or incorporated into transgenic plants is currently a priority research area (Moellenbeck et al. 1995). Historically, tolerance associated with size of the root system (Ortman et al. 1968, Branson 1986) or regrowth of roots after rootworm injury (Riedell 1989) has been the predominate resistance mechanism found in maize hybrids. Riedell and Evenson (1993) evaluated larval feeding tolerance of singlecross maize hybrids representing three successive 10 -yr eras. Genotypes did not exhibit antibiosis to western corn rootworm larvae, but vertical root pull resistance values for 1980 and 1970-era genotypes were significantly greater than those for 1960-era genotypes. Even when 1980-era genotypes had higher grain yield than 1970 and 1960-era genotypes at different levels of infestation, tolerance had not eliminated grain yield loss to rootworm larvae at low and moderate plant densities (Riedell and Evenson 1993). Godfrey et al. (1993a) found that Pioneer hybrid 3377 
compensated by increasing vegetative tissue biomass (leaf, stem, and root) in response to larval injury, which appeared to be at the expense of reproductive tissue biomass and yield. Gray and Steffey (1998) reported a variety of root regrowth and yield patterns of maize hybrids that were subjected to rootworm injury. Some hybrids followed the response pattern reported by Godfrey et al. (1993a) and others did not.

A greater understanding of maize yield responses to rootworm injury and potential compensatory mechanisms may open new avenues for plant breeders to exploit when designing pest resistant plants (Trumble et al. 1993) and also may help to improve economic injury levels, predictive models of pest interactions, and the design of alternative control strategies (Godfrey et al. 1993b). Experiments conducted to study yield responses of maize to rootworm injury have only focused on yellow dent hybrids. Little information on this response variable is available for different types of maize (e.g., white dent hybrids and popcorn). Food grade maize (especially white dent) is becoming more important for United States producers and is a staple in other parts of the world where the western corn rootworm is a pest. Therefore, the two objectives of this study were as follows: (1) to characterize yield responses of yellow dent hybrids, white dent hybrids, and a popcorn hybrid after larval injury occurs, and (2) determine if relative yield responses to larval western corn rootworm injury are similar among hybrids.

\section{Materials and Methods}

This study was conducted at the University of Nebraska Agricultural Research and Development Center near Mead, NE. Three yellow dent hybrids (Pioneer 3346, 3394, and 3377), a white dent hybrid (Noble Bear 742W), and a popcorn hybrid (Purdue 612) were included in experiment 1. Four white dent hybrids (Pioneer 3281W, 3287W; Noble Bear 739W, 749W) and a yellow dent hybrid (Pioneer 3377) were included in experiment 2 . Pioneer 3377 was included as a historical standard (1980s era hybrid). A split-plot design with four replications was used. Hybrids were the whole plots and rootworm infestation levels were the subplots (experiment 1: 0 and 1,000 eggs per 30.5 cm row; experiment 2: 0, 200,500, and 1,000 eggs per $30.5 \mathrm{~cm}$ row). Whole plots (each $6.1 \mathrm{~m}$ long) consisted of four rows in experiment 1 and eight rows in experiment 2 separated by two border rows. Each subplot was two rows. Maize plots were established where soybeans had been grown the previous year in a Sharpsburg silty clay loam soil. Experiment 1 was planted on 18 May 1995 and 20 May 1996; experiment 2 was planted on 18 May 1995 and 17 May 1996. The seeding rate was 60,500 kernels per hectare in rows spaced $0.76 \mathrm{~m}$ apart. Standard weed and fertilizer programs were used each year. Plots were spring disked and harrowed before planting. Daily air temperature, rainfall, and water applied by irrigation were recorded during each experiment.

Western corn rootworm eggs (Dixon County, NE, population, eggs from field collected adults) were suspended in a $0.125 \%$ concentration of agar-water, and infested after planting at the two- to three-leaf growth stage, using a modification of the techniques described by Sutter and Branson (1986). To estimate rootworm age structure, samples of soil cubes (15.2 $\mathrm{cm}^{3}$ ) each surrounding a maize plant were periodically taken and were processed using the method of Bergman et al. (1981). Larvae within roots were recovered by suspending each root system over a container of water and forcing larvae to move from roots with heat. In experiment 1 , samples were taken on five dates during 1995 (26 June-11 July period), and on six dates during 1996 (25 June-15 July period). In experiment 2, samples were taken on four dates in 1995 (29 June-17 July period), and on six dates in 1996 (15 June-12 July period). To evaluate root damage, samples were taken during the peak damage period (experiment 1: 11 July 1995 and 15 July 1996; experiment 2: 17 July 1995 and 12 July 1996) when most larvae were third instars. Root damage was evaluated using a 1-6 rating scale (Hills and Peters 1971). In experiment 1 , two plants in 1995 and one plant in 1996 were sampled per treatment per replication. In experiment 2 , one plant was sampled per treatment per replication in both years. Adult emergence also was used as an indicator of the magnitude of larval infestation. Emergence cages (Hein et al. 1985) were placed in plots before the start of adult emergence. One cage was placed in each treatment subplot per replication.

Yield. Maize was harvested on 16 October 1995 and 12 October 1996. Bulk yields were measured by weighing the shelled dry grain production from a 3-m row section per treatment per replication. Within year and experiment, the number of plants harvested per 3-m row was not significantly different among treatments. The number and weight of kernels per ear also was recorded from four plants in 0 and 1,000 egg treatments per replication in experiment 1 and experiment 2 (1995 only, labor constraints prevented data collection in 1996).

Statistical Analysis. Yield response variables were analyzed each year with the MIXED procedure (SAS Institute 1985) in accordance with statistical model (split-plot design) and factorial treatment design. Fisher protected least significant difference (LSD) test was used to determine significant differences among treatment means. Regression analyses were used to quantify the relationship between larvae per treatment and yield in experiment 2. A significance level of $P<0.05$ was used for all experiments.

\section{Results}

Environmental Conditions. Average temperatures and rainfall for the research site in 1995 and 1996 are presented in Table 1. In general, both years were colder and dryer than the average over the previous 18 yr. In each year, rainfall was greater in May and lower from June to September (especially 1995) than the long-term average. 
Table 1. Mean temperature and rainfall, 1995 and 1996

\begin{tabular}{|c|c|c|c|c|c|c|c|c|}
\hline \multirow{2}{*}{ Month } & \multicolumn{3}{|c|}{ Mean temp, ${ }^{\circ} \mathrm{C}$} & \multicolumn{3}{|c|}{ Rainfall, mm } & \multicolumn{2}{|c|}{ Irrigation, $\mathrm{mm}$} \\
\hline & 1995 & 1996 & Normal & 1995 & 1996 & Normal & 1995 & 1996 \\
\hline May & 13.5 & 15.0 & 19.9 & 134 & 173 & 105.4 & - & - \\
\hline June & 21.8 & 23.0 & 22.5 & 23.1 & 79.8 & 107.0 & 18.5 & - \\
\hline July & 25.1 & 22.5 & 25.2 & 78.0 & 47.6 & 83.0 & 18.7 & 53.1 \\
\hline Aug & 26.1 & 22.2 & 23.6 & 36.2 & 67.1 & 90.8 & - & - \\
\hline Sept & 17.4 & 16.7 & 18.8 & 58.0 & 88.7 & 88.7 & - & - \\
\hline Mean & 20.8 & 19.9 & 22.0 & 65.8 & 91.3 & 95.0 & & \\
\hline
\end{tabular}

Normal temperature and rainfall are based on 18-yr averages from the University of Nebraska Agricultural Research and Development Center near Mead, NE.

Rootworm Population Dynamics and Larval Injury. Across hybrids, larval densities $( \pm \mathrm{SE})$ averaged 13.9 \pm 1.7, $9.6 \pm 1.3$, (experiment 1, 1995 and 1996, respectively) $11.8 \pm 1.2$, and $10.9 \pm 1.4$ (experiment 2,1995 and 1996, respectively) per $15.2 \mathrm{~cm}$ soil cube for the 1,000 eggs per $\mathrm{cm}$ row treatment and $0.4 \pm 1.7,0.0 \pm$ 1.3 , (experiment 1, 1995 and 1996, respectively) $0.6 \pm$ 1.2 , and $0.0 \pm 1.4$ (experiment 2, 1995 and 1996, respectively) per soil cube in uninfested plots. Rootworm injury was significantly greater in infested than noninfested plants in each experiment each year (Urías-López et al. 2000), but the level of injury, resulting from the highest infestation level was only above the commonly used economic injury index (3.0 root damage rating, Mayo 1986) during $1 \mathrm{yr}$ for each experiment (root damage ratings across hybrids, 1,000 eggs per $30.5 \mathrm{~cm}$ row infestation level and uninfested, respectively: experiment $1,1995: 2.9 \pm 0.1,1.0 \pm 0.1$; 1996: $3.9 \pm 0.1,1.0 \pm 0.1$; experiment $2,1995: 3.4 \pm 0.2$, $1.3 \pm 0.2 ; 1996: 2.9 \pm 0.1,1.2 \pm 0.1)$.

Grain Yield, Experiment 1. Across hybrids, bulk yield of noninfested plants was significantly greater than infested plants in $1996(F=15.79 ; \mathrm{df}=1,15 ; P<$ 0.01 ), but not in 1995 (Table 2). The number of kernels per ear from a four plant subsample was significantly greater in noninfested than infested plants across hybrids in $1995(F=8.40 ; \mathrm{df}=1,15 ; P<0.05)$ but not in 1996 (Table 2). The weight per kernel was not

Table 2. Yield parameters $( \pm \mathrm{SE})$ of infested and noninfested plants across hybrids, experiment 1

\begin{tabular}{rrrr}
\hline \hline $\begin{array}{c}\text { Infestation } \\
\text { level }^{a}\end{array}$ & $\begin{array}{c}\text { Bulk yield } \\
(\mathrm{kg})^{b}\end{array}$ & $\begin{array}{c}\text { Kernels per }^{c} \\
\text { ear }\end{array}$ & $\begin{array}{c}\text { Weight of }^{c} \\
\text { kernels, g }\end{array}$ \\
\hline \multicolumn{3}{c}{1995} \\
0 & $1.78 \pm 0.07 \mathrm{a}$ & $606.6 \pm 24.3 \mathrm{a}$ & $0.26 \pm 0.01 \mathrm{a}$ \\
1,000 & $1.64 \pm 0.07 \mathrm{a}$ & $543.1 \pm 24.3 \mathrm{~b}$ & $0.28 \pm 0.01 \mathrm{a}$ \\
& \multicolumn{3}{c}{1996} \\
0 & $2.38 \pm 0.05 \mathrm{a}$ & $583.3 \pm 16.1 \mathrm{a}$ & $0.26 \pm 0.01 \mathrm{a}$ \\
1,000 & $2.09 \pm 0.05 \mathrm{~b}$ & $581.2 \pm 16.1 \mathrm{a}$ & $0.25 \pm 0.01 \mathrm{a}$ \\
\hline
\end{tabular}

Means within year and column followed by the same letter are not statistically different $(P>0.05$; Fisher protected LSD test).

${ }^{a}$ Infestation level values are western corn rootworm eggs per 30.5 cm row.

${ }^{b}$ Bulk yield is dry weight, taken from four sample values (each 3-m row); $13.1 \pm 0.3$ and $12.2 \pm 0.3$ plants were harvested in 1995 and 1996 , respectively, per 3-m row.

${ }^{c}$ Kernels per ear and weight per ear were derived from a four-plant subsample per treatment per replicate; each number is the average of 80 sample values. significantly different between infested and noninfested plants across hybrids in either year.

In both years there were significant differences in bulk yield (1995: $F=35.16$; $\mathrm{df}=4,12 ; P<0.01 ; 1996$ : $F=35.16 ; \mathrm{df}=1,12 ; P<0.01)$, and kernels per ear $(1995: F=8.40 ; \mathrm{df}=4,12 ; P<0.05 ; 1996: F=4.39 ; \mathrm{df}=$ 4,$12 ; P<0.05$ ) among hybrids (Table 3 ). The interaction between hybrid and rootworm injury significantly affected bulk yield in $1996(F=3.22 ; \mathrm{df}=4,15$; $P<0.05)$ but not in 1995. In 1996, bulk yield was significantly greater in noninfested than infested plants for Pioneer 3394, Noble Bear 742W, and Pioneer 3377 , but no yield differences occurred between rootworm treatments for Purdue 612 or Pioneer 3346 (Table 4).

Grain Yield, Experiment 2. Across hybrids, yield differences among levels of infestation were significant in $1995(F=2.12 ; \mathrm{df}=3,45 ; P<0.05)$, but not in 1996. In 1995, yield of plants infested with 500 and 1000 eggs per $30.5 \mathrm{~cm}$ row was significantly less than noninfested plants or plants infested with 200 eggs per $30.5 \mathrm{~cm}$ row (Table 5). Across hybrids, the number of kernels per ear from a four plant subsample was significantly greater in noninfested plants than plants with the greatest injury in $1995(F=6.64 ; \mathrm{df}=1,15$; $P<0.05$ ) (Table 5). In 1995, the weight per kernel was not significantly different among infestation levels across hybrids.

In both years, there were no significant differences in bulk yield and kernels per ear among hybrids. The interaction between hybrid and rootworm injury significantly affected bulk yield in $1995(F=2.12$; df $=$ $12,45 ; P<0.05)$. Different yield response patterns were apparent among some hybrids. Noble Bear $739 \mathrm{~W}$ exhibited a significant linear yield response to different larval population levels $\left[P=0.013, R^{2}=0.974, y=\right.$ $2.054+(-0.0497) x]$. As the number of larvae per plant increased the yield decreased (Table 6). A significant cubic relationship between yield and larvae per plant occurred for Noble Bear 749W $[P=0.012$, $\left.R^{2}=0.976, y=2.138+(-0.00012) x^{3}\right]$. An overcompensatory trend was apparent in that yield increased at the lowest infestatation level and then declined at greater infestation levels (Table 6). Pioneer 3377 exhibited a similar overcompensatory pattern but the cubic relationship was not significant. Pioneer 3287 and 3281 did not exhibit a significant yield response to 
Table 3. Yield parameters $( \pm \mathrm{SE})$ across infestation levels of different hybrids, experiment 1

\begin{tabular}{|c|c|c|c|c|c|c|}
\hline \multirow{2}{*}{ Hybrid } & \multicolumn{3}{|c|}{1995} & \multicolumn{3}{|c|}{1996} \\
\hline & Bulk yield, $\mathrm{kg}^{a}$ & Kernels per ear $^{b}$ & Weight per kernel, $g^{b}$ & Bulk yield, $\mathrm{kg}^{b}$ & Kernels per ear ${ }^{b}$ & Weight per kernel, g \\
\hline P3394 & $2.24 \pm 0.10 \mathrm{a}$ & $688.5 \pm 38.1 \mathrm{a}$ & $0.32 \pm 0.01 \mathrm{a}$ & $2.48 \pm 0.10 \mathrm{a}$ & $558.5 \pm 28.3 \mathrm{ab}$ & $0.31 \pm 0.01 \mathrm{a}$ \\
\hline P3377 & $2.06 \pm 0.10 \mathrm{ab}$ & $673.7 \pm 38.0 \mathrm{a}$ & $0.29 \pm 0.01 \mathrm{a}$ & $2.57 \pm 0.10 \mathrm{a}$ & $635.4 \pm 28.3 \mathrm{a}$ & $0.29 \pm 0.01 \mathrm{a}$ \\
\hline P3346 & $1.86 \pm 0.10 \mathrm{bc}$ & $558.5 \pm 38.2 \mathrm{a}$ & $0.29 \pm 0.01 \mathrm{a}$ & $2.68 \pm 0.10 \mathrm{a}$ & $632.8 \pm 28.3 \mathrm{a}$ & $0.25 \pm 0.01 b$ \\
\hline NB742 & $1.67 \pm 0.10 \mathrm{c}$ & $551.1 \pm 39.6 \mathrm{ab}$ & $0.29 \pm 0.01 \mathrm{a}$ & $2.49 \pm 0.10 \mathrm{a}$ & $591.7 \pm 28.3 \mathrm{a}$ & $0.31 \pm 0.01 \mathrm{a}$ \\
\hline Purdue 612 & $0.74 \pm 0.10 \mathrm{~d}$ & $498.2 \pm 38.0 \mathrm{~b}$ & $0.15 \pm 0.01 b$ & $0.97 \pm 0.10 \mathrm{~b}$ & $492.9 \pm 28.3 b$ & $0.14 \pm 0.01 \mathrm{c}$ \\
\hline
\end{tabular}

Means within a column followed by the same letter are not statistically different. $(P>0.05$; Fisher protected LSD test).

${ }^{a}$ Bulk yield is dry weight, taken from four sample values (each 3-m row); $13.1 \pm 0.3$ and $12.2 \pm 0.3$ plants were harvested in 1995 and 1996 , respectively, per 3-m row.

${ }^{b}$ Kernels per ear and weight per kernel were derived from a four-plant subsample per treatment per replicate; each number is the average of 32 sample values.

the infestation levels in experiment 2 (yield was similar across infestation levels, Table 6).

\section{Discussion}

In both experiments, yield response to larval injury was different in each year. This may have been primarily because of the level of rootworm injury that was present in 1995 versus 1996. In experiment 1 (1995) and experiment 2 (1996) the maximum larval injury resulted only in feeding scars and minor root pruning on most plants without significant yield loss. The mean root damage rating across hybrids was $2.9 \pm$ 0.1 , which is near the minimum root injury index $(2.50-2.75)$ that has been reported to cause economic yield loss in yellow dent hybrids (e.g., Turpin et al. 1972, Stamm et al. 1985, Gray and Steffey 1998). In experiment 2 (1995: mean root rating $3.4 \pm 0.2$ ) and experiment 1 (1996: mean root rating $3.9 \pm 0.1$ ), root injury resulted in the equivalent of one node of roots pruned to near the base of the root on some plants and was associated with a 12.2 and $9.7 \%$ yield reduction, respectively, across hybrids.

Data indicate that the minimum level of injury needed to significantly reduce yield in white maize hybrids was similar to that reported by Mayo (1986) for yellow hybrids. Mean root damage ratings $<3.0 \mathrm{did}$ not significantly affect yield but ratings between 3.3 and 4.0 resulted in yield loss. This is not surprising because white and yellow maize are closely related; both belong to the dent group (Berger 1962, Dowswell et al. 1996). Low levels of rootworm injury did not significantly affect grain yield even though reductions in photosynthetic rate and growth response patterns could be measured during vegetative growth stages (Urías-López et al. 2000). This supports the idea (Sutter et al. 1990, Gray et al. 1993) that maize can tolerate and compensate for some level of early season larval injury without sustaining significant yield loss.

In 1996 in experiment 1 and 1995 in experiment 2, the interaction of hybrid and rootworm injury significantly affected yield which suggests that biomass partitioning in response to rootworm injury and other stresses (e.g., environmental) may differ among hybrids. In experiment 1, with similar levels of injury across hybrids (Table 4), grain yield of Pioneer 3346 and Purdue 612 was not significantly reduced while significant decreases in yield occurred in Pioneer 3377 (16.4\%), Pioneer 3394 (22.7\%), and Noble Bear 742 (14.2\%). The difference in response of infested Pioneer 3346 and Pioneer 3394 yellow maize hybrids was especially apparent. Larval populations, adult emergence, and root damage ratings were very similar for

Table 4. Yield, root damage, and rootworm population parameters $( \pm \mathrm{SE})$ per hybrid and infestation level, experiment 1 , 1996

\begin{tabular}{|c|c|c|c|c|c|}
\hline Hybrid & $\begin{array}{c}\text { Infestation } \\
\text { level }^{a}\end{array}$ & Bulk yield, $\mathrm{kg}^{b}$ & Larvae per plant & $\begin{array}{l}\text { Root damage }^{c} \\
\quad(1-6 \text { scale })\end{array}$ & Adults per trap \\
\hline \multirow[t]{2}{*}{ P3394 } & 0 & $2.80 \pm 0.1 \mathrm{a}$ & $0.0 \pm 2.4$ & $1.0 \pm 0.2$ & $2.3 \pm 7.1$ \\
\hline & 1,000 & $2.16 \pm 0.1 b$ & $11.0 \pm 2.4$ & $4.2 \pm 0.2$ & $25.5 \pm 7.1$ \\
\hline \multirow[t]{2}{*}{ Purdue 612} & 0 & $0.98 \pm 0.1 \mathrm{a}$ & $0.0 \pm 2.4$ & $1.0 \pm 0.2$ & $6.5 \pm 7.1$ \\
\hline & 1,000 & $0.95 \pm 0.1 \mathrm{a}$ & $4.5 \pm 2.4$ & $4.2 \pm 0.2$ & $27.0 \pm 7.1$ \\
\hline \multirow[t]{2}{*}{ NB742 } & 0 & $2.68 \pm 0.1 \mathrm{a}$ & $0.0 \pm 2.4$ & $1.0 \pm 0.2$ & $4.8 \pm 7.1$ \\
\hline & 1,000 & $2.29 \pm 0.1 b$ & $12.7 \pm 2.4$ & $3.3 \pm 0.2$ & $9.8 \pm 7.1$ \\
\hline \multirow[t]{2}{*}{ P3346 } & 0 & $2.65 \pm 0.1 \mathrm{a}$ & $0.0 \pm 2.4$ & $1.0 \pm 0.2$ & $3.8 \pm 7.1$ \\
\hline & 1,000 & $2.71 \pm 0.1 \mathrm{a}$ & $9.0 \pm 2.4$ & $4.0 \pm 0.2$ & $26.5 \pm 7.1$ \\
\hline \multirow[t]{2}{*}{ P3377 } & 0 & $2.80 \pm 0.1 \mathrm{a}$ & $0.0 \pm 2.4$ & $1.0 \pm 0.2$ & $3.5 \pm 7.1$ \\
\hline & 1,000 & $2.34 \pm 0.1 b$ & $10.5 \pm 2.4$ & $3.8 \pm 0.2$ & $39.0 \pm 7.1$ \\
\hline
\end{tabular}

Means within hybrid and column followed by the same letter are not statistically different $(P>0.05$; Fisher protected LSD test). Larvae per plant, root damage rating and adults per trap are significantly different among infestation levels (SAS MIXED model main effect, $P<0.05)$; numbers are averages of eight sample values.

${ }^{a}$ Infestation level values are western corn rootworm eggs per $30.5 \mathrm{~cm}$ row.

${ }^{b}$ Bulk yield is dry weight, taken from four sample values (each 3-m row); $13.1 \pm 0.3$ and $12.2 \pm 0.3$ plants were harvested in 1995 and 1996 , respectively per $3-\mathrm{m}$ row.

${ }^{c}$ Root damage rating scale (Hills and Peters 1971). 
Table 5. Yield parameters $( \pm S E)$ of infested and noninfested plants across hybrids, experiment 2

\begin{tabular}{|c|c|c|c|}
\hline $\begin{array}{c}\text { Infestation } \\
\text { level }^{a}\end{array}$ & $\begin{array}{c}\text { Bulk yield, } \\
\mathrm{kg}^{b}\end{array}$ & $\begin{array}{l}\text { Kernels per } \\
\text { ear }^{c}\end{array}$ & $\begin{array}{l}\text { Weight per } \\
\text { kernel, gm }{ }^{c}\end{array}$ \\
\hline \multicolumn{4}{|c|}{1995} \\
\hline 0 & $2.07 \pm 0.06 \mathrm{a}$ & $625.2 \pm 22.7 \mathrm{a}$ & $0.28 \pm 0.01 \mathrm{a}$ \\
\hline 200 & $2.02 \pm 0.06 \mathrm{a}$ & - & - \\
\hline 500 & $1.90 \pm 0.06 b$ & - & - \\
\hline 1,000 & $1.87 \pm 0.06 \mathrm{~b}$ & $553.7 \pm 22.7 \mathrm{~b}$ & $0.27 \pm 0.01 \mathrm{a}$ \\
\hline \multicolumn{4}{|c|}{1996} \\
\hline 0 & $2.02 \pm 0.06 \mathrm{a}$ & - & - \\
\hline 200 & $2.02 \pm 0.06 \mathrm{a}$ & - & - \\
\hline 500 & $1.94 \pm 0.06 \mathrm{a}$ & - & - \\
\hline 1,000 & $1.92 \pm 0.06 \mathrm{a}$ & - & - \\
\hline
\end{tabular}

Means within a column followed by the same letter are not statistically different $(P>0.05$; Fisher protected LSD test $) ;-$, not recorded.

${ }^{a}$ Infestation level values are western corn rootworm eggs per 30.5 cm row.

${ }^{b}$ Bulk yield is dry weight, taken from 20 sample values (each 3-m row); $11.6 \pm 0.4$ and $12.1 \pm 0.3$ plants were harvested in 1995 and 1996 , respectively, per 3-m row.

${ }^{c}$ Kernels per ear and weight per kernel were derived from a 20 plant subsample per treatment per replicate; each number is the average of 80 sample values.

the two hybrids in 1996 (Table 4) but infested Pioneer 3346 out-yielded infested 3394 by $20.3 \%$ (Table 4 ).

The yield response patterns to different levels of injury were very different among some hybrids in experiment 2 during 1995. For example, maximum yield reduction in Noble Bear 739 and 749 was similar (16.6 and $17.1 \%$, respectively) but 739 exhibited a significant linear yield response and 749 a significant cubic yield response across infestation levels (Table 6). In contrast, Pioneer 3287 did not exhibit a negative or positive yield response with increasing larval injury even though maximum root injury ratings were similar to Noble Bear 739 (Table 6). Within the range of injury that occurred in experiment 2 , yield response patterns included tolerance, overcompensation, compensation, and linear components of the generalized damage curve that has been outlined by Pedigo et al. (1986). Data from this experiment complements those of Allee and Davis (1996) and Gray and Steffey (1998) who also reported different biomass partitioning and yield responses of yellow dent hybrids subjected to rootworm injury.

Establishing a western corn rootworm injury-yield relationship in maize has been difficult because the relationship is influenced by various biological, environmental, and agronomic factors (Mayo 1986). It is generally accepted that some critical level of larval injury is needed before economic yield loss will occur but the injury level leading to significant yield loss has varied widely in published studies (e.g., Turpin et al. 1972, Mayo 1986, Sutter et al. 1990, Davis 1994, Gray and Steffey 1998). It is also well documented that environmental interactions (especially moisture stress) with rootworm injury can influence grain yield (Chiang et al. 1980, Spike and Tollefson 1991, Riedell et al. 1992, Roth et al. 1995, Allee and Davis 1996, Gray and Steffey 1998). The interactive effects of hybrid
Table 6. Yield, root damage, and rootworm population parameters $( \pm \mathrm{SE})$ for each hybrid and infestation level, experiment 2,1995

\begin{tabular}{lrrrc}
\hline \hline Hybrid & $\begin{array}{c}\text { Infestation } \\
\text { level }^{a}\end{array}$ & $\begin{array}{c}\text { Bulk yield } \\
\text { level, kg }\end{array}$ & $\begin{array}{c}\text { Larvae per } \\
\text { plant }^{c}\end{array}$ & $\begin{array}{c}\text { Root damage } \\
\text { (1-6 scale) }\end{array}$ \\
\hline P3377 & 0 & $2.29 \pm 0.12$ & $0.0 \pm 2.3$ & $1.0 \pm 0.3$ \\
& 200 & $2.39 \pm 0.12$ & $4.5 \pm 2.3$ & $2.2 \pm 0.3$ \\
& 500 & $1.90 \pm 0.12$ & $10.2 \pm 2.3$ & $2.5 \pm 0.3$ \\
P3287 & 1,000 & $2.04 \pm 0.12$ & $14.0 \pm 2.3$ & $3.2 \pm 0.3$ \\
& 0 & $1.98 \pm 0.12$ & $0.5 \pm 2.3$ & $1.8 \pm 0.3$ \\
& 200 & $1.88 \pm 0.12$ & $5.5 \pm 2.3$ & $2.8 \pm 0.3$ \\
& 500 & $1.97 \pm 0.12$ & $11.0 \pm 2.3$ & $2.5 \pm 0.3$ \\
NB739 & 1,000 & $1.97 \pm 0.12$ & $9.2 \pm 2.3$ & $3.8 \pm 0.3$ \\
& 0 & $2.05 \pm 0.12$ & $0.0 \pm 2.3$ & $1.0 \pm 0.3$ \\
& 200 & $1.91 \pm 0.12$ & $3.2 \pm 2.3$ & $2.0 \pm 0.3$ \\
NB749 & 500 & $1.72 \pm 0.12$ & $7.2 \pm 2.3$ & $2.8 \pm 0.3$ \\
& 1,000 & $1.71 \pm 0.12$ & $6.5 \pm 2.3$ & $4.0 \pm 0.3$ \\
& 0 & $2.10 \pm 0.12$ & $1.5 \pm 2.3$ & $1.5 \pm 0.3$ \\
& 200 & $2.15 \pm 0.12$ & $4.5 \pm 2.3$ & $2.0 \pm 0.3$ \\
P3281 & 500 & $2.05 \pm 0.12$ & $9.8 \pm 2.3$ & $2.8 \pm 0.3$ \\
& 1,000 & $1.74 \pm 0.12$ & $15.0 \pm 2.3$ & $3.5 \pm 0.3$ \\
& 0 & $1.93 \pm 0.12$ & $0.8 \pm 2.3$ & $1.0 \pm 0.3$ \\
& 200 & $1.75 \pm 0.12$ & $1.5 \pm 2.3$ & $2.0 \pm 0.3$ \\
& 500 & $1.85 \pm 0.12$ & $9.5 \pm 2.3$ & $2.8 \pm 0.3$ \\
& 1,000 & $1.89 \pm 0.12$ & $14.2 \pm 2.3$ & $2.8 \pm 0.3$ \\
\hline
\end{tabular}

${ }^{a}$ Infestation level values are western corn rootworm eggs per 30.5 cm row.

${ }^{b}$ Bulk yield is dry weight, taken from 20 sample values (each 3-m row); $11.6 \pm 0.4$ and $12.1 \pm 0.3$ plants were harvested in 1995 and 1996 , respectively, per $3-\mathrm{m}$ row.

${ }^{c}$ Root damage rating scale (Hills and Peters 1971), numbers are the averages of four sample values.

and rootworm injury on yield (Allee and Davis 1996, Gray and Steffey 1998, this study) suggest that maize hybrids may inherently differ in their ability to tolerate injury and partition biomass in response to injury and other stresses. This may be an important factor that has been underexploited by plant breeders who traditionally have focused on early season injury and the prevention of injury (e.g., search for antibiosis, development of transgenic plants). The complex interaction between hybrid, level of injury, and other stresses suggests that a common western corn rootworm injury-yield relationship may not exist within maize.

\section{Acknowledgments}

We thank J. Brown, M. Barnhart, C. Darnell, T. Malousek, and J. Malousek, for field or laboratory assistance on this project. We thank L. Byrkit (Noble Bear Seeds) and J. Campbell (Pioneer Hi-Bred International) for providing seed for the project, and J. E. Foster and L. G. Higley for their critical reviews of the manuscript. The research was supported in part by the University of Nebraska Agricultural Experiment Station Project 17-058, CONACYT-Mexico, and Pioneer HiBred International. This is paper No. 13025 of the Journal Series of the University of Nebraska Agricultural Research Division and contribution No. 1043 of the Department of Entomology, University of Nebraska.

\section{References Cited}

Allee, L. L., and P. M. Davis. 1996. Effect of manure on maize tolerance to western corn rootworm (Coleoptera: Chrysomelidae). J. Econ. Entomol. 89: 1608-1620. 
Apple, J. W., H. C. Chiang, L. M. English, L. J. French, A. J. Keaster, G. F. Krause, Z B Mayo, J. D. Munson, G. J. Musick, J. C. Owens, and others. 1977. Impact of northern and western corn rootworm larvae on field corn. North Central Res. Publ. 239. University of Wisconsin, Madison.

Berger, J. 1962. Corn production and the manuring of corn. Conzett \& Hubner, Zurich, Switzerland.

Bergman, M. K., J. J. Tollefson, and P. N. Hinz. 1981. Sampling scheme for estimating populations of corn rootworm larvae. Environ. Entomol. 10: 986-990.

Branson, T. F. 1986. Larval feeding behavior and host-plant resistance in maize, pp. 159-182. In J. L. Krysan and T. A. Miller [eds.], Methods for study of pest Diabrotica. Springer, New York.

Chiang, H. C., L. K. French, and D. E. Rasmussen. 1980. Quantitative relationship between western corn rootworm population and corn yield. J. Econ. Entomol. 73: 665-666.

Chiang, H. C. 1973. Bionomics of the northern and western corn rootworm. Annu. Rev. Entomol. 18: 47-72.

Davis, P. M. 1994. Comparison of economic injury levels for western corn rootworm (Coleoptera: Chrysomelidae) infesting silage and grain corn. J. Econ. Entomol. 87: 10861090.

Dowswell, C. R., R. L. Paliwal, and R. P. Cantrell. 1996. Corn in the third world. Westview, Boulder, CO.

Godfrey, L. D., L. J. Meinke, and R. J. Wright. 1993a. Vegetative and reproductive biomass accumulation in field corn: response to root injury by western corn rootworm (Coleoptera: Chrysomelidae). J. Econ. Entomol. 86: 1557-1573.

Godfrey, L. D., L. J. Meinke, and R. J. Wright. 1993b. Affects of larval injury by western corn rootworm (Coleoptera: Chrysomelidae) on gas exchange parameters of field corn. J. Econ. Entomol. 85: 1546-1556.

Gray, M. E., and K. L. Steffey. 1998. Corn rootworm (Coleoptera: Chrysomelidae) larval injury and root compensation of 12 maize hybrids: an assessment of the economic injury index. J. Econ. Entomol. 91: 723-740.

Gray, M. E., K. L. Steffey, and H. Oloumi-Sadeghi. 1993. Participatory on-farm research in Illinois corn fields: an evaluation of established soil insecticide rates and prevalence of corn rootworm (Coleoptera: Chrysomelidae) injury. J. Econ. Entomol. 86: 1473-1482.

Hein, G. L., M. K. Bergman, R. G. Bruss, and J. J. Tollefson. 1985. Absolute sampling technique for corn rootworm (Coleoptera: Chrysomelidae) adult emergence that adjusts to fit common row spacing. J. Econ. Entomol. 78: 1503-1506.

Hills, T. M., and D. C. Peters. 1971. A method of evaluating postplanting insecticide treatments for control of western corn rootworm larvae. J. Econ. Entomol. 64: 764-765.

Levine, E., and H. Oloumi-Sadeghi. 1991. Management of diabroticite rootworms in corn. Annu. Rev. Entomol. 36: $229-255$.

Mayo, Z B. 1986. Field evaluation of insecticides, pp. 183203. In J. L. Krysan and T. A. Miller [eds.], Methods for the study of pest Diabrotica. Springer, New York.

Metcalf, R. L. 1986. Forward, pp. vii-xv. In Methods for the study of pest Diabrotica. Springer, New York.

Moellenbeck, D. J., B. D. Barry, and L. L. Darrah. 1995. Tripsacum dactyloides (Gramineae) seedlings for host plant resistance to the western corn rootworm (Coleoptera: Chrysomelidae). J. Econ. Entomol. 88: 18011803.

Ortman, E. E., D. C. Peters, and P. J. Fitzgerald. 1968. Vertical-pull techniques for evaluating tolerance of corn rootworm systems to northern and western corn rootworm. J. Econ. Entomol. 61: 373-375.

Palmer, L. T., and T. Kommedahl. 1969. Root-infesting Fusarium species in relation to rootworm infestations in corn. Phytopathology. 59: 1613-1617.

Pedigo, L. P., S. H. Hutchins, and L. G. Higley. 1986. Economic injury levels in theory and practice. Annu. Rev. Entomol. 31: 341-368.

Riedell, W. E. 1989. Western corn rootworm damage in maize: greenhouse technique and plant response. Crop Sci. 29: 412-415.

Riedell, W. E. 1990. Western corn rootworm damage or mechanical root cutting: effects on root morphology and water relations in maize. Crop Sci. 30: 628-631.

Riedell, W. E., and A. Y. Kim. 1990. Anatomical characterization of western corn rootworm damage in adventitious roots of corn. J. Iowa Acad. Sci. 97: 15-17.

Riedell, W. E., and P. D. Evenson. 1993. Rootworm feeding tolerance in single-cross corn hybrids from different eras. Crop. Sci. 33: 951-955.

Riedell, W. E., R. D. Gustin, and D. L. Beck. 1992. Effect of irrigation on root growth and yield of plants damaged by western corn rootworm. Maydica 37: 143-148.

Roth, G. W., D. D. Calvin, and S. Lueloff. 1995. Tillage, nitrogen timing, and planting date effects on western corn rootworm injury to corn. Agron. J. 87: 189-193.

SAS Institute. 1985. SAS user's guide: statistics. SAS Institute, Cary, NC.

Spike, B. P., and J. J. Tollefson. 1991. Yield response of corn subjected to western corn rootworm (Coleoptera: Chrysomelidae) infestation and lodging. J. Econ. Entomol. 84: 1585-1590.

Stamm, D. E., Z B Mayo, J. B. Campbell, J. F. Witkowski, L. W. Anderson, and R. Kozub. 1985. Western corn roootworm (Coleoptera: Chrysomelidae) beetle counts as a means of making control recommendations in $\mathrm{Ne}-$ braska. J. Econ. Entomol. 78: 794-98.

Steffey, K. L., M. E. Gray, and J. T. Shaw. 1994. Corn hybrid response to corn rootworm injury, pp. 68-72. In 1994 Proceedings, Illinois Agriculture and Pesticides Conference. Cooperative Extension Service, University of Illinois, Urbana-Champaign.

Sutter, G. R., and T. F. Branson. 1986. Artificial infestations of field plots, pp. 147-157. In J. L. Krysan and T. A. Miller [eds.], Methods for the study of pest Diabrotica. Springer. New York.

Sutter, G. R., J. R. Fisher, N. C. Elliott, and T. F. Branson. 1990. Effect of insecticide treatments on root lodging and yield of corn in controlled infestations of western corn rootworm (Coleoptera: Chrysomelidae). J. Econ. Entomol. 83: 2414-2420.

Trumble, J. T., D. M. Kolodny-Hirsch, and I. P. Ting. 1993. Plant compensation for arthropod herbivory. Annu. Rev. Entomol. 38: 93-119.

Turpin, F. T., L. C. Dumenil, and D. C. Peters. 1972. Edaphic and agronomic characteristics that affect potential for rootworm damage to corn in Iowa. J. Econ. Entomol. 65: 1615-1619.

Urías-López, M. A., L. J. Meinke, L. G. Higley, and F. J. Haile. 2000. Influence of western corn rootworm (Coleoptera: Chrysomelidae) larval injury on photosynthetic rate and vegetative growth of different types of maize. Environ. Entomol. 29: 861-867.

Received for publication 20 March 2000; accepted 9 October 2000. 